\title{
Metastatic Intracerebral Chondrosarcoma: Case Report and Literature Review of Endocrine Effects and Management Paradigms
}

\author{
Namath S. Hussain ${ }^{1}$, Sara H. Ahmed ${ }^{2}$ \\ 1. Neurological Surgery, Loma Linda University Medical Center, Loma Linda, USA 2. Endocrinology, Anaheim Regional \\ Medical Center, Anaheim, USA
}

Corresponding author: Namath S. Hussain, namath.hussain@gmail.com

\begin{abstract}
The most common underlying diagnosis of intracranial tumor pathology is metastatic disease, followed by primary brain tumors. Chondrosarcomatous metastatic disease of the brain is a rare subtype of this disease process.
\end{abstract}

The patient presented with right-sided weakness. Her history was significant for femur chondrosarcoma which was resected and treated. Laboratory analysis revealed persistent hypercalcemia and hyperglycemia. MRI of the brain was completed, which revealed a left parietal-occipital lesion with smaller lesions in the left frontal and right parietal lobe.

Multidisciplinary tumor board recommended surgery for lesion resection and pathology. Surgical pathologic diagnosis after lesion resection was metastatic chondrosarcoma. The patient's preoperative arm and leg weakness improved after surgery.

Our paper delineates this unique case of intracranial spread of femur chondrosarcoma.

Categories: Endocrinology/Diabetes/Metabolism, Pathology, Neurosurgery

Keywords: chondrosarcoma, intracranial, metastasis, hypercalcemia

\section{Introduction}

Malignant tumors arising from the skeletal system are rare, representing only about $0.5 \%$ of all new cancers. Approximately 2100 new cases of malignant bone cancers (sarcomas) occur in the United States each year. The most common type of bone cancer is osteosarcoma. About one-fourth of malignant bone cancers are chondrosarcomas.

Received 04/13/2020 Review began 05/17/2020 Review ended 05/21/2020 Published 06/02/2020

() Copyright 2020 Hussain et al. This is an open access article distributed under the terms of the Creative Commons Attribution License CC-BY 4.0., which permits unrestricted use, distribution, and reproduction in any medium, provided the original author and source are credited.
The most common cause of neoplastic intracranial mass lesions is metastatic disease, followed by primary brain tumors. Recent studies have shown that brain metastases make up about $49 \%$ of intracranial neoplasms while gliomas make up $26 \%$, followed by meningiomas, pituitary adenomas, and schwannomas. The most common metastatic tumors to the central nervous system are lung, breast, prostate, and renal carcinomas. Chondrosarcomatous metastatic disease to the brain is exceedingly rare [1-3]. Isolated cases of metastatic disease from intracranial sources have been observed; however, chondrosarcoma metastasizing to the brain from an extracranial source has not yet been reported in the literature.

\section{Case Presentation}

The patient is a 51-year-old female who came to the emergency department with complaints of right-sided weakness after a recent trip to Mexico. Physical exam revealed 4/5 motor strength in the right arm and leg. An MRI of the brain with and without contrast was obtained, which revealed ring-enhancing lesion in the left parietal-occipital lobe (Figure 1). Smaller lesions were also seen in the left frontal and right parietal intraparenchymal regions. A more in-depth review of her medical history revealed that she had a remote history of left femur chondrosarcoma, which was diagnosed after she had developed severe hip pain in the past. She later developed tumor spread to the lung as well at that time. She also had persistent hypercalcemia and hyperglycemia even after a gross total resection of the femur lesion. She recovered after her femur surgery and was subsequently discharged to home at that time. 


\section{Cureus}


FIGURE 1: Preoperative and postoperative magnetic resonance imaging of the brain revealing a ring-enhancing mass in the left parieto-occipital lobe.

Based on the patient's previous history and diagnostic studies, our differential diagnosis was intracranial metastasis, primary brain tumor, and neurocysticercosis. Craniotomy for lesion resection and biopsy for pathology was performed, significant for metastatic chondrosarcoma in the resected mass (Figure 2).

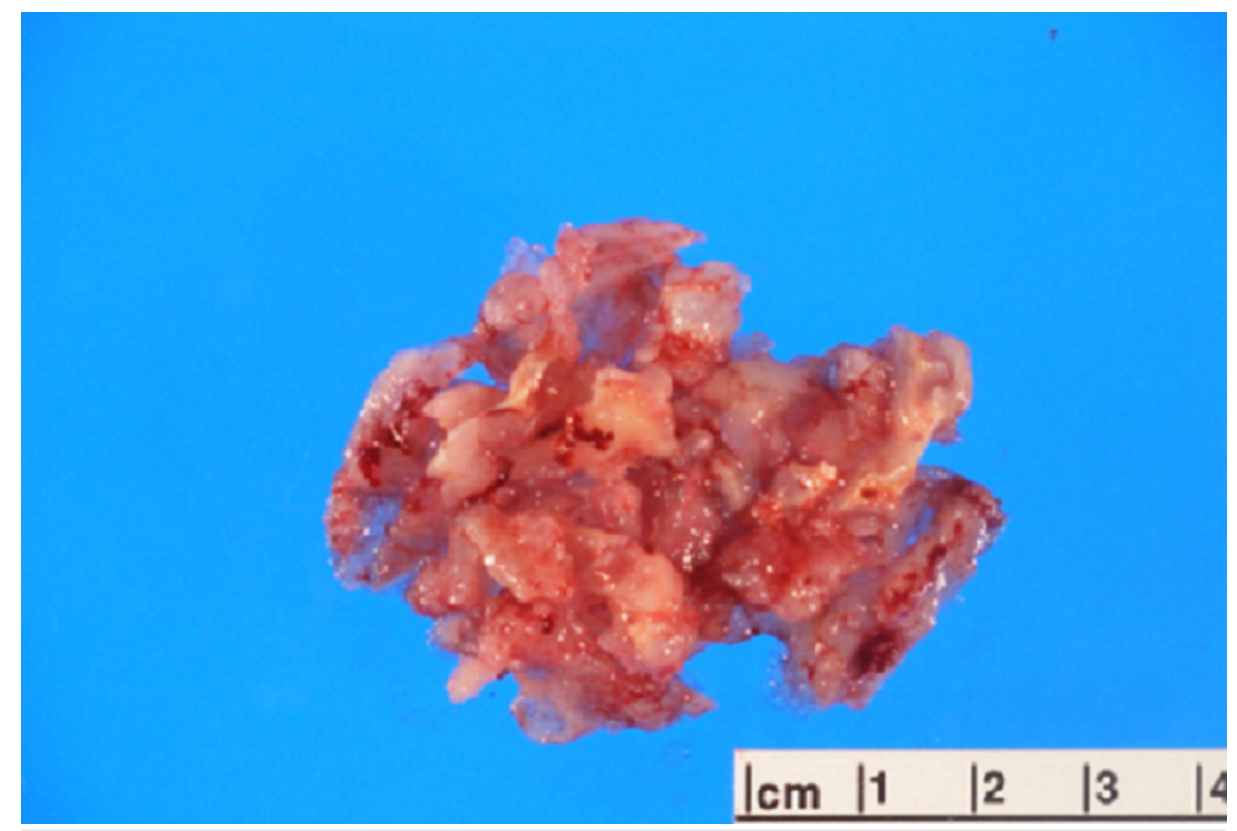

FIGURE 2: Photograph showing multiple fragments of gray-white, gelatinous multilobulated tissue mass with adherent glistening matrix.

Cytology and pathology stain slides were described as sheets of chondrocytes separated by bands of myxoid stroma. The individual cells were anaplastic with mitoses and pleomorphism (Figures 3-8). 


\section{Cureus}

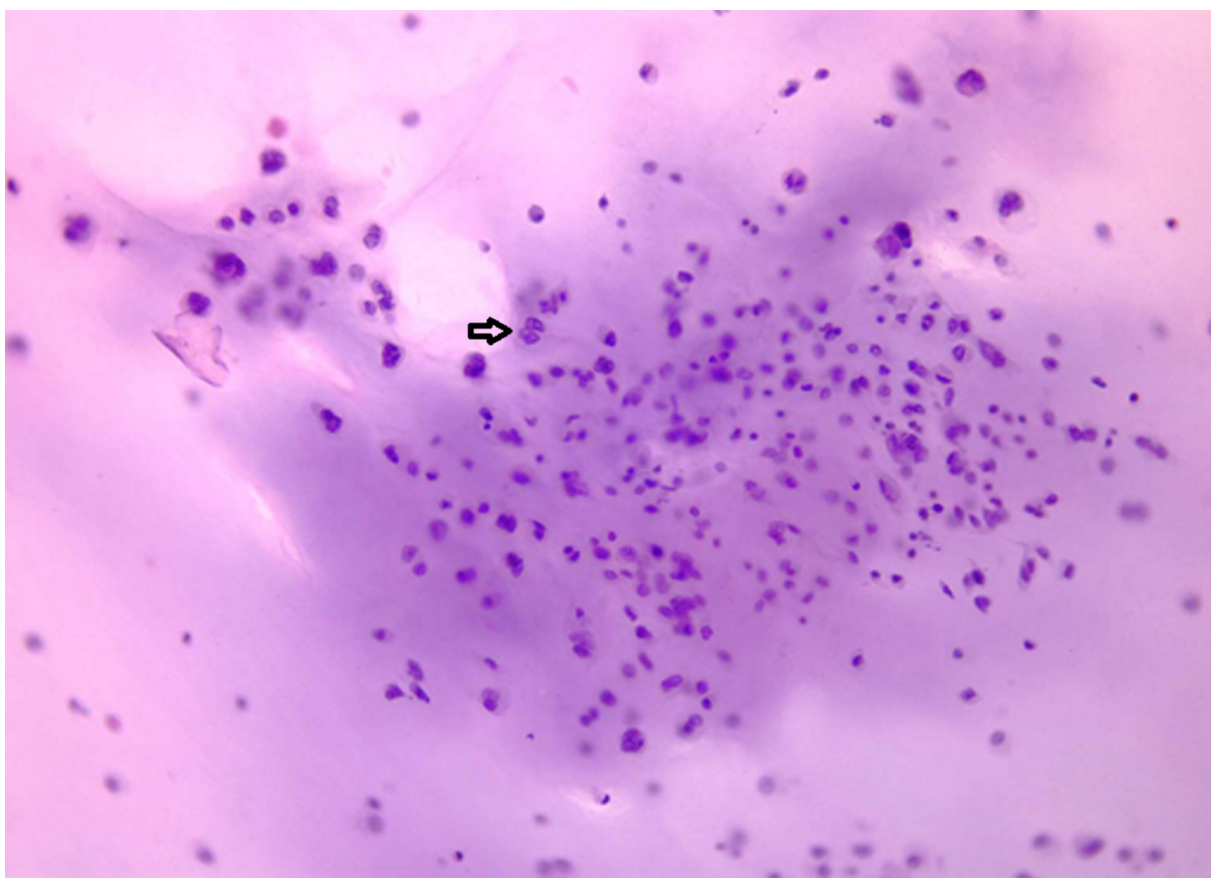

FIGURE 3: Cytologic smear from gelatinous aspirate showing atypical chondrocytes within a pool of blue mucinous extracellular matrix (papanicolaou stain, original magnification $\times 100$ ).

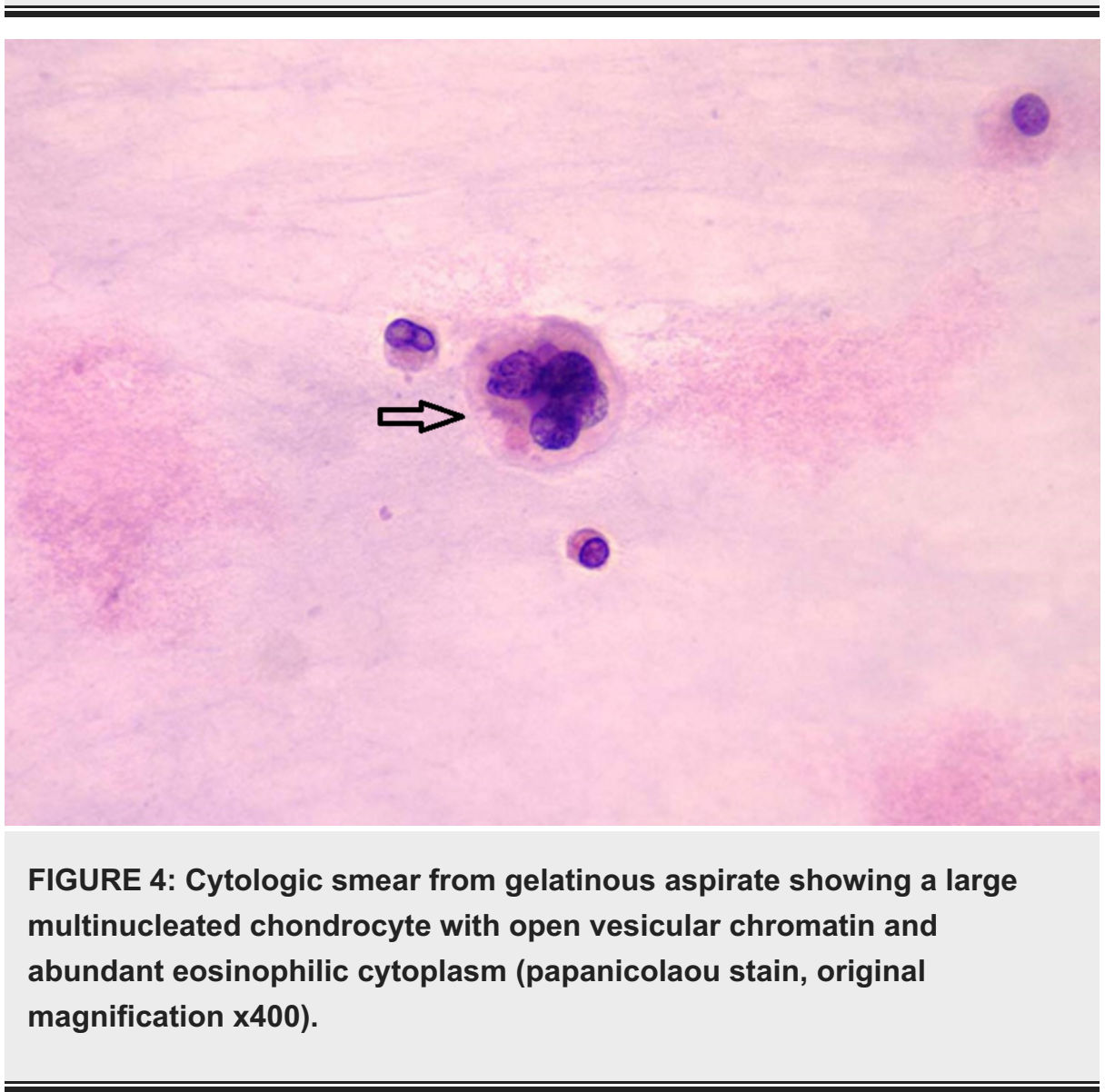




\section{Cureus}

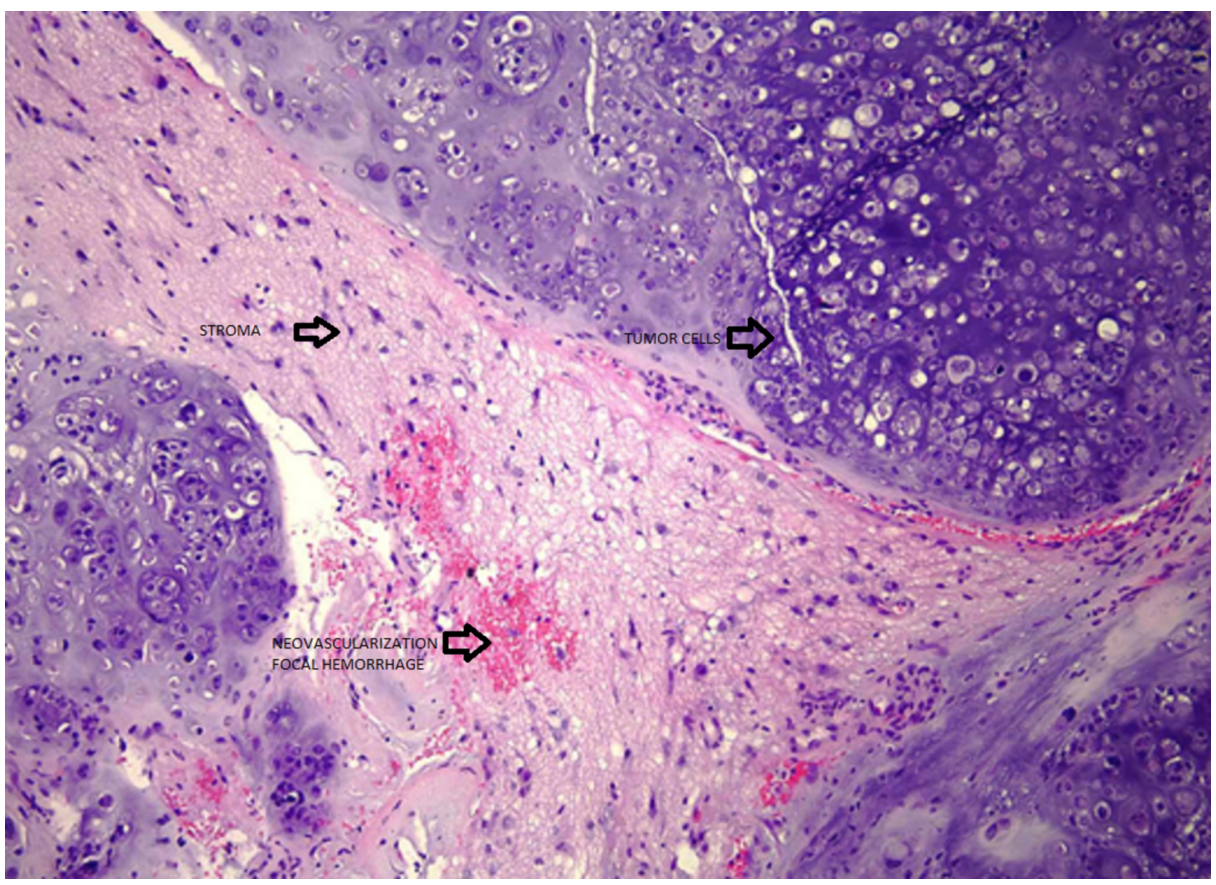

FIGURE 5: Low power view of chondrosarcoma with nests of tumor cells separated by bands of abundant myxoid stroma. Note neovascularization and focal hemorrhage (hematoxylin-eosin stain, original magnification $\mathbf{x 1 0 0 )}$.

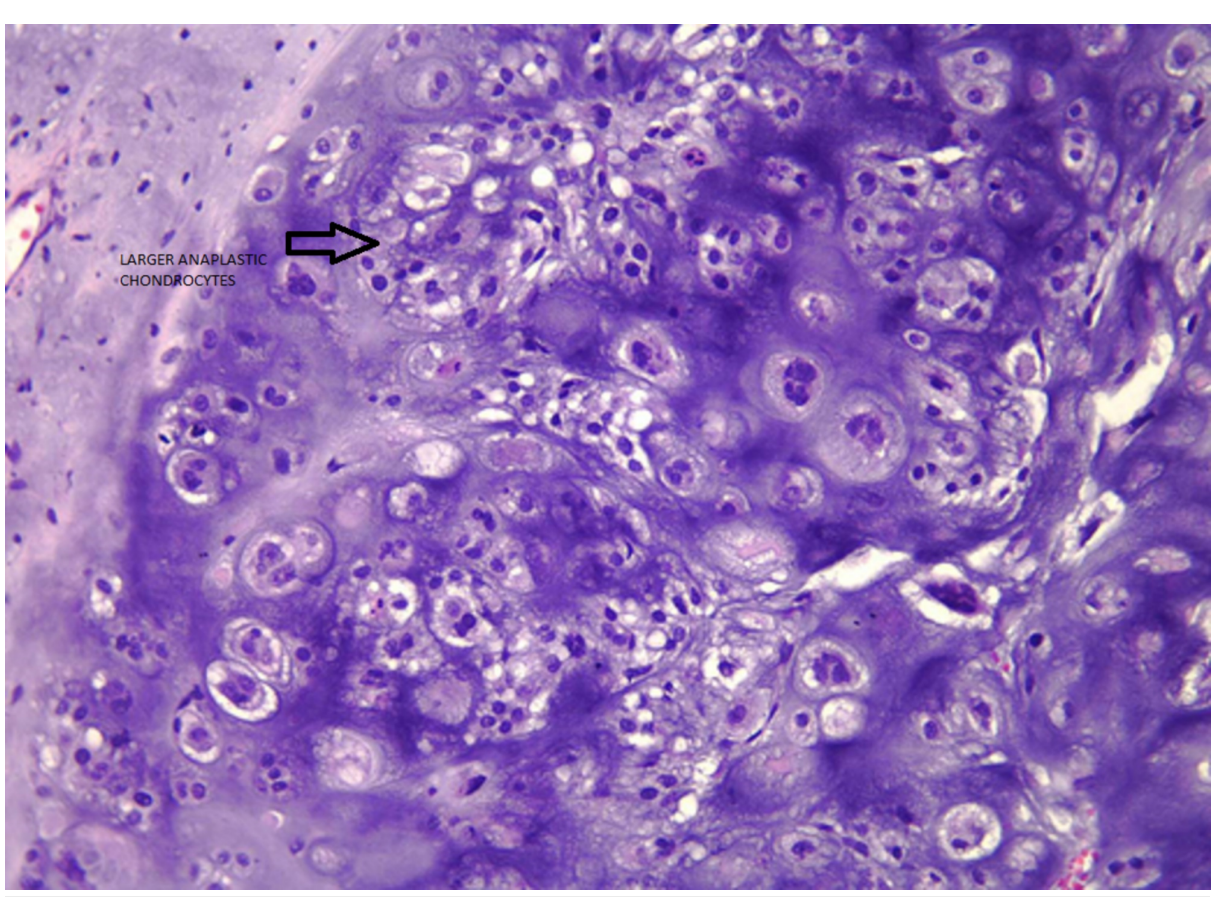

FIGURE 6: Malignant chondrocytes displaying cellular pleomorphism. Unevenly spaced cells and nests of cells vary in size, shape, and distribution. Larger, more anaplastic chondrocytes exhibit multinucleation, nucleomegaly, and cytoplasmic vacuolization. The extracellular matrix shows a high degree of variability in density (hematoxylin-eosin stain, original magnification $\times 400$ ). 


\section{Cureus}

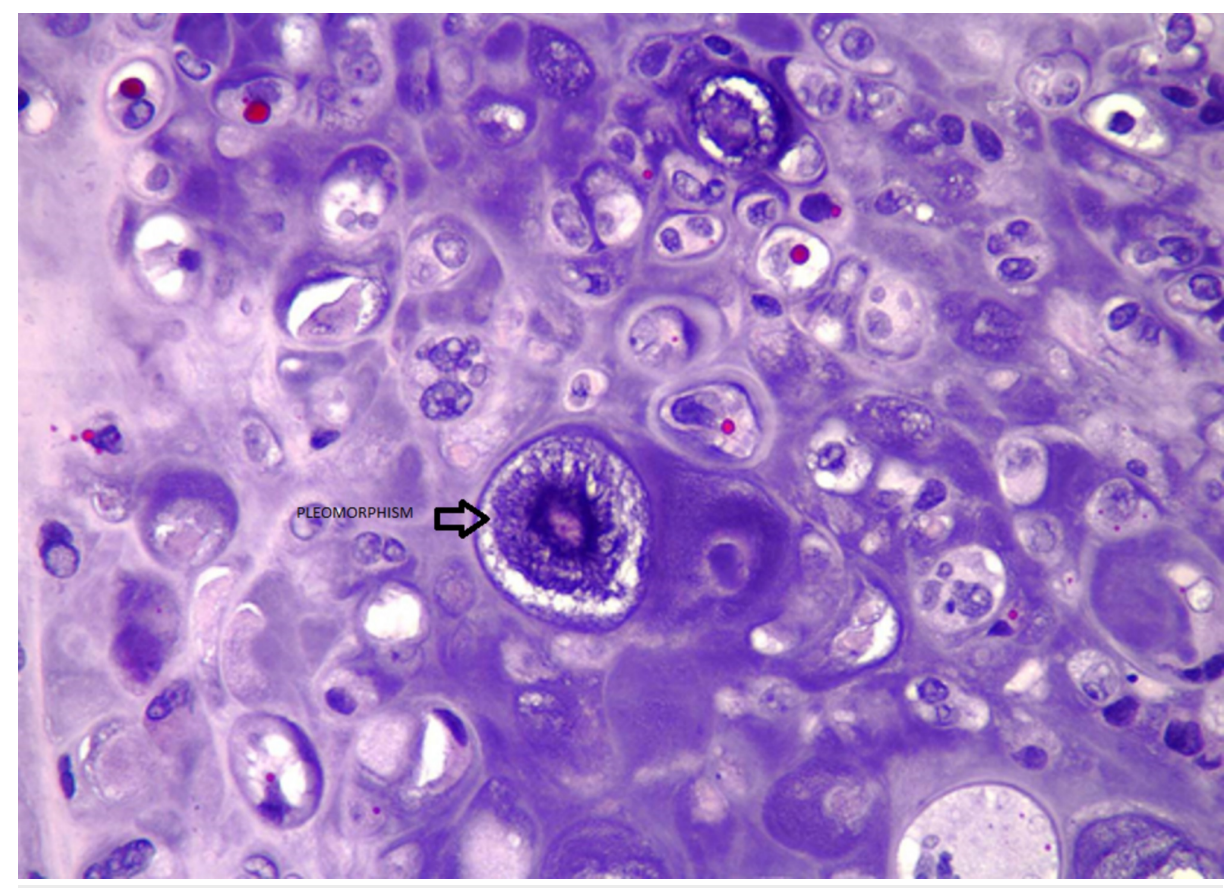

FIGURE 7: Malignant chondrocytes displaying cellular pleomorphism. Large, anaplastic chondrocytes exhibit bizarre nuclear and cytoplasmic morphology (hematoxylin-eosin stain, original magnification x400).

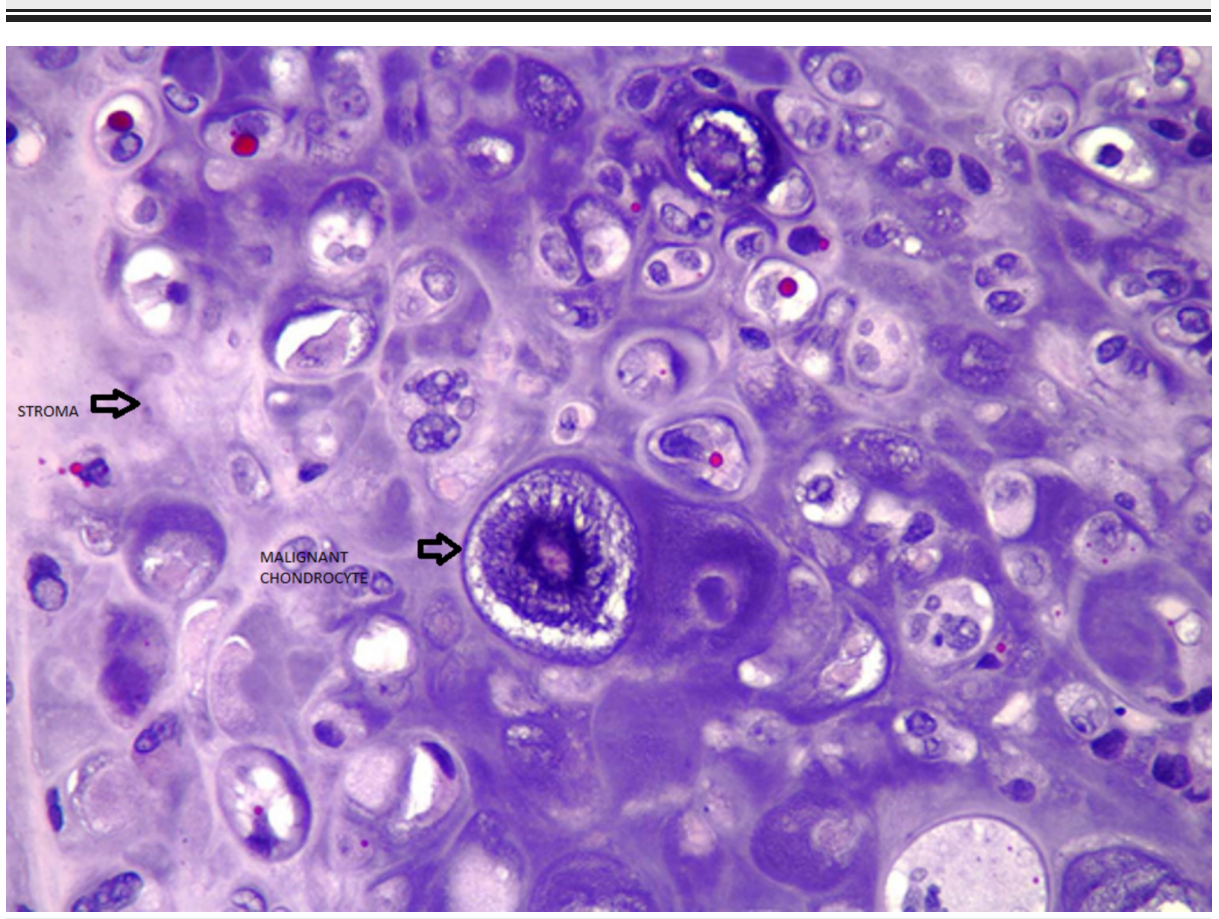

FIGURE 8: 200x magnification revealing hypercellular, malignant chondrocytes in nests and cords displaying frequent mitoses, multinucleation, and nucleomegaly. The extracellular myxoid stroma shows abundant variability in density (hematoxylin-eosin stain, original magnification $\times 200$ ).

After surgical resection, Gliadel local chemotherapy was used. Her weakness improved after surgery. On delayed follow-up, her hyperglycemia and hypercalcemia improved as well. 


\section{Cureus}

\section{Discussion}

Chondrosarcomas account for close to one quarter of all primary malignant bone tumors. These lesions typically present in older males. They are located in the femur, tibia, or humerus $50 \%$ of the time. Less common locations are the pelvis and spine. They can present as a painful lump or as a pathological fracture of weakened bone.

On imaging these lesions can be a lytic pattern or deep endosteal scalloping and soft-tissue extension. Some have high T2 signal indicative of high-water content and endochondral ossification.

Approximately 50 cases of primary intracranial chondrosarcoma have been reported (Table 1) [1-17]. Intracranial tumors of chondrosarcomatous origin represent less than $0.16 \%$ of all primary brain tumors [5]. A comprehensive literature review did not reveal any previously reported case of intracranial metastatic chondrosarcoma from an extracranial source. 


\begin{tabular}{|c|c|c|c|c|c|c|}
\hline Age/Sex & $\begin{array}{l}1^{\circ} \\
\text { or } \\
2^{\circ}\end{array}$ & Location & Treatment & Results & Year & Author \\
\hline $12 / \mathrm{M}$ & $1^{\circ}$ & frontoethmoid bone & GTR & no recurrence & 2005 & $\begin{array}{l}\text { Jroundi et } \\
\text { al. [12] }\end{array}$ \\
\hline $28 / F$ & $1^{\circ}$ & parafalcine & GTR & no recurrence & 2003 & $\begin{array}{l}\text { Kothary et } \\
\text { al. [13] }\end{array}$ \\
\hline $17 / F$ & $1^{\circ}$ & frontoparietal cortex & GTR & recurrences at 16 and 19 months & 2002 & $\begin{array}{l}\text { Gonzalez- } \\
\text { Lois et al. } \\
\text { [8] }\end{array}$ \\
\hline 69/M & $1^{\circ}$ & right frontal cortex & GTR & death in 4 weeks due to septic chock & 2002 & $\begin{array}{l}\text { Chaskis et } \\
\text { al. [2] }\end{array}$ \\
\hline $17 / F$ & $1^{\circ}$ & temporoparietal cortex & GTR & recurrence and death in 3 weeks & 2001 & $\begin{array}{l}\text { Marshman } \\
\text { et al. [14] }\end{array}$ \\
\hline $46 / F$ & $1^{\circ}$ & frontoparietal cortex & GTR & no recurrence & 2000 & $\begin{array}{l}\text { Oikawa et } \\
\text { al. [15] }\end{array}$ \\
\hline $12 / F$ & $1^{\circ}$ & falx & $\begin{array}{l}\text { GTR, EB radiation } \\
\text { (SSagS involved) }\end{array}$ & progression free & 1998 & $\begin{array}{l}\text { Gerszten et } \\
\text { al. [7] }\end{array}$ \\
\hline $13 / \mathrm{F}$ & $1^{\circ}$ & dura mater & GTR, rad & recurrence in 21 months & 1993 & $\begin{array}{l}\text { Cho et al. } \\
\text { [4] }\end{array}$ \\
\hline $11 / \mathrm{F}$ & $1^{\circ}$ & left parietal cortex & GTR, rad & recurrence and death in 18 months & 1992 & $\begin{array}{l}\text { Chhem et } \\
\text { al. [3] }\end{array}$ \\
\hline 11/M & $1^{\circ}$ & left occipital & STR & recurrence at 6 months & 1979 & $\begin{array}{l}\text { Rollo et al. } \\
\text { [18] }\end{array}$ \\
\hline $14 / F$ & $1^{\circ}$ & deep parenchyma & none & death in 8 years & 1989 & $\begin{array}{l}\text { Parker et al. } \\
{[16]}\end{array}$ \\
\hline $\begin{array}{l}69 / \mathrm{M} \\
60 / \mathrm{M}\end{array}$ & $1^{\circ}$ & right temporal bone & GTR & $\begin{array}{l}\text { (1) no recurrence at } 3 \text { years, (2) no } \\
\text { recurrence at } 10 \text { months }\end{array}$ & 1985 & $\begin{array}{l}\text { Adegbite et } \\
\text { al. [1] }\end{array}$ \\
\hline $\begin{array}{l}33 / \mathrm{F} \\
65 / \mathrm{M}\end{array}$ & $1^{\circ}$ & $\begin{array}{l}\text { right posterior fossa, left } \\
\text { petrous bone }\end{array}$ & GTR/rads, GTR & $\begin{array}{l}\text { (1) no recurrence at } 3 \text { years, (2) no } \\
\text { recurrence at } 10 \text { months }\end{array}$ & 1985 & $\begin{array}{l}\text { Hassounah } \\
\text { et al. [10] }\end{array}$ \\
\hline $26 / F$ & $1^{\circ}$ & left and right frontoparietal & $\begin{array}{l}\text { GTR, superior sag } \\
\text { sinus resected }\end{array}$ & intraop death & 1980 & $\begin{array}{l}\text { Heros et al. } \\
{[11]}\end{array}$ \\
\hline $59 / \mathrm{M}$ & $1^{\circ}$ & right frontal & STR, rads & no recurrence at 7 months & 1980 & $\begin{array}{l}\text { Richman et } \\
\text { al. [17] }\end{array}$ \\
\hline $28 / F$ & $1^{\circ}$ & falx & GTR, iodine seeds & recurrence in 8 months & 1992 & $\begin{array}{l}\text { Salcman et } \\
\text { al. [19] }\end{array}$ \\
\hline $\begin{array}{l}20 / F \\
12 / F\end{array}$ & $1^{\circ}$ & $\begin{array}{l}\text { Spheno-occip } \\
\text { synchondrosis, maxillary } \\
\text { sinus }\end{array}$ & GTR & (1) LTC, (2) death in 3 days & 1978 & $\begin{array}{l}\text { Cianfriglia } \\
\text { et al. [5] }\end{array}$ \\
\hline
\end{tabular}

\section{TABLE 1: Chondrosarcoma of the brain.}

GTR: Gross total resection; EB: External beam; STR: Subtotal resection.

Various presentations of primary and metastatic disease from intracranial sources are found in the neurosurgical literature. There have been cases reported on chondrosarcoma causing hyperostosis of the overlying cranium [15]. There have also been reported cases of primary meningeal chondrosarcoma in the literature $[15,16]$. In terms of lesion diagnosis, there has been a report of using lamellar inclusions in the rough endoplasmic reticulum as a marker for diagnosis. Other associated diagnostic markers include immunohistochemical positivity for S-100 protein, vimentin, and collagen type II [17]. 
Accepted treatment methods for primary lesions have usually included total surgical resection; however, there is currently no consensus on adjuvant therapy. Cases utilizing brachytherapy and external beam radiation have been reported with some success [7,16]. Magnetic resonance imaging has come to be accepted as the gold standard in the diagnosis of intracerebral metastatic disease, including chondrosarcoma, with perfusion imaging being the most recent advance in this diagnostic paradigm [13].

A review of papers studying the rationale for using BCNU wafers in the treatment of intracranial metastatic disease reveals that not only are the results promising but also that the mechanism of delivering local chemotherapy directly at the tumor site and obviating the blood-brain barrier can lead to higher local effective concentrations of the drug without systemic toxicity [6, 9]. Randomized, prospective trials are still needed to further elucidate the utility of surgery versus radiosurgery versus local delivery of chemotherapeutic agents to in an effort to bypass the blood-brain barrier.

Hypercalcemia is a common complication of malignancy and occurs in up to $30 \%$ of cancer patients. Mild cases of hypercalcemia can cause non-specific symptoms such as lethargy, nausea, and abdominal pain, whereas severe cases can lead to severe dehydration and neurological impairment such as coma. There are several mechanisms that result in hypercalcemia in malignancy. Secretion of parathyroid-related peptide (PTH-rp) by malignant cells, which induces renal calcium absorption, accounts for $80 \%$ of cases. Excess osteolytic activity with bone resorption accounts for $30 \%$ of cases, and is usually seen in extensive skeletal tumor burden. Increased production of 1,25-dihydroxyvitamin D, which enhances intestinal calcium absorption as well as osteolytic bone resorption, accounts for $1 \%$ of cases of malignancy-related hypercalcemia [18].

Hyperglycemia in cancer patients can be attributed to a few proposed mechanisms aside from a known diagnosis of diabetes mellitus. Steroids, which are used in a number of malignancy-related settings such as for cerebral edema from brain metastasis or in several chemotherapy regimens, are a common cause of druginduced hyperglycemia. In the hospital setting, more than $50 \%$ of patients receiving high-dose steroids experience at least one episode of hyperglycemia [19]. Another mechanism for elevated serum glucose levels in critically ill patients is stress-induced hyperglycemia, which results from excess release of counterregulatory hormones, including epinephrine, cortisol, and glucagon. Patient-associated risk factors that have been described in developing both steroid-induced and stress-induced hyperglycemia include older age and higher body mass index [19,20].

\section{Conclusions}

Chondrosarcomatous brain tumors are rare with few primary cases reported in the literature. We report a case of a metastatic intracranial metastasis from an extracranial source, which has not been previously reported. Our case demonstration should help to clarify adjuvant treatment options. Treatment plans should take into account histopathological characteristics of the tumor along with patient functional status, endocrine status, and ability to tolerate adjuvant treatment side-effects. Future studies should address neurocognitive outcomes in addition to recurrence and survival rates with pathological correlation when comparing different treatment algorithms.

\section{Additional Information \\ Disclosures}

Human subjects: Consent was obtained by all participants in this study. Conflicts of interest: In compliance with the ICMJE uniform disclosure form, all authors declare the following: Payment/services info: All authors have declared that no financial support was received from any organization for the submitted work. Financial relationships: All authors have declared that they have no financial relationships at present or within the previous three years with any organizations that might have an interest in the submitted work. Other relationships: All authors have declared that there are no other relationships or activities that could appear to have influenced the submitted work.

\section{References}

1. Adegbite AB, McQueen DJ, Paine KW, Rozdilsky B: Primary intracranial chondrosarcoma: a report of two cases. Neurosurgery. 1985, 17:490-494. 10.1227/00006123-198509000-00017

2. Chaskis C, Michotte A, Goossens A, Stadnik T, Koerts G, D'Haens J: Primary intracerebral myxoid chondrosarcoma: case illustration. J Neurosurg. 2002, 97:228. 10.3171/jns.2002.97.1.0228

3. Chhem RK, Bui BT, Calderon-Villar H, Fontaine S: Case report: primary mesenchymal chondrosarcoma of the brain. Clin Radiol. 1992, 45:422-423. 10.1016/s0009-9260(05)81007-4

4. Cho BK, Chi JG, Wang KC, Chang KH, Choi KS: Intracranial mesenchymal chondrosarcoma: a case report and literature review. Childs Nerv Syst. 1993, 9:295-299. 10.1007/bf00306279

5. Cianfriglia F, Pompili A, Occhipinti E: Intracranial malignant cartilaginous tumours. Report of two cases and review of literature. Acta Neurochir. 1978, 45:163-175. 10.1007/bf01774391

6. Ewend MG, Elbabaa S, Carey LA: Current treatment paradigms for the management of patients with brain metastases. Neurosurgery. 2005, 57:66-77. 10.1227/01.neu.0000182739.84734.6e

7. Gerszten PC, Pollack IF, Hamilton RL: Primary parafalcine chondrosarcoma in a child . Acta Neuropathol. 1997, 95:111-114. 10.1007/s004010050773 
8. Gonzalez-Lois C, Cuevas C, Abdullah O, Ricoy JR: Intracranial extraskeletal myxoid chondrosarcoma: case report and review of the literature. Acta Neurochir. 2002, 144:735-740. 10.1007/s00701-002-0949-y

9. Guerin C, Olivi A, Weingart JD, Lawson HC, Brem H: Recent advances in brain tumor therapy: local intracerebral drug delivery by polymers. Invest New Drugs. 2004, 22:27-37. 10.1023/b:drug.0000006172.65135.3e

10. Hassounah M, Al-Mefty O, Akhtar M, Jinkins JR, Fox JL: Primary cranial and intracranial chondrosarcoma: a survey. Acta Neurochir. 1985, 78:123-132. 10.1007/bf01808691

11. Heros RC, Martinez AJ, Ahn HS: Intracranial mesenchymal chondrosarcoma. Surg Neurol. 1980, 14:311-317.

12. Jroundi L, Kacemi L, Bounhir B, Chami I, Boujida N, Bacadi D: Intracerebral chondrosarcoma in a 12 year old child. (Article in French). J Radiol. 2005, 86:173-175. 10.1016/s0221-0363(05)81340-x

13. Kothary N, Law M, Cha S, Zagzag D: Conventional and perfusion MR imaging of parafalcine chondrosarcoma. AJNR Am J Neuroradiol. 2003, 24:245-248.

14. Marshman LA, Gunasekera L, Rose PE, Olney IS: Primary intracerebral mesenchymal chondrosarcoma with rhabdomyosarcomatous differentiation: case report and literature review. Br J Neurosurg. 2001, 15:419-424. $10.1080 / 02688690120082431$

15. Oikawa H, Satoh T, Masuda T, Arai H, Ehara S, Muro-oka G: Intracranial low-grade chondrosarcoma with hyperostosis of the skull: a case report. J Neuro-Onc. 2000, 49:249-254. 10.1023/a:1006498209279

16. Parker JR, Zarabi MC, Parker JC Jr: Intracerebral mesenchymal chondrosarcoma. Ann Clin Lab Sci. 1989, 19:401-407.

17. Richman AV, Balis GA, Maniscalco JE: Primary intracerebral tumor with mixed chondrosarcoma and glioblastoma--gliosarcoma or sarcoglioma?. J Neuropathol Exp Neurol. 1980, 39:329-335. 10.1097/00005072-198005000-00007

18. Rollo JL, Green WR, Kahn LB: Primary meningeal mesenchymal chondrosarcoma. Arch Pathol Lab Med. 1979, 103:239-243.

19. Salcman M, Scholtz H, Kristt D, Numaguchi Y: Extraskeletal myxoid chondrosarcoma of the falx. Neurosurgery. 1992, 31:344-348. 10.1227/00006123-199208000-00021

20. Sato K, Kubota T, Yoshida K, Murata H: Intracranial extraskeletal myxoid chondrosarcoma with special reference to lamellar inclusions in the rough endoplasmic reticulum. Acta Neuropathol. 1993, 86:525-528. $10.1007 /$ bf00228591 